\title{
KADIPATEN CIANCANG DALAM PERSPEKTIF LOKAL
}

\author{
Dewi Ratih * \\ Dosen Program Studi Pendidikan Sejarah FKIP-Universitas Galuh Ciamis \\ Jl. R. E. Martadinata No. 150 Ciamis, 46274 Jawa Barat
}

\begin{abstract}
ABSTRAK
Perkembangan sejarah Kabupaten Galuh berawal dari berdirinya kerajaan di Kabupaten Ciamis yang biasa disebut dengan Kerajaan Galuh atau Kerajaan Sunda Galuh. Kerajaan Galuh ini diungkapkan dalam beberapa sumber sejarah, baik melalui naskah atau prasasti. Naskah yang menyebutkan Kerajaan Galuh ini tergolong kedalam historiografi tradisional yang didalamnya mengandung unsur mitos, dongeng, legenda, dan unsur-unsur yang bersifat historis. Beberapa naskah yang menceritakan tentang Kerajaan Galuh karenanya banyak menggunakan historiografi tradisional, maka sebuah penulusuran penulisan sejarah Galuh secara ilmiah sangat dibutuhkan untuk penulisannya secara kritis. Penelitian ini menggunakan metode penelitian historis yang terbagi menjadi empat tahapan kerja. Pertama, heuristik yakni tahap pengumpulan sumber. Kedua, kritik yang terbagi menjadi kritik eksternal dan kritik internal, ketiga, interpretasi yaitu penafsiran sumber, dan terakhir adalah historiografi atau penulisan sejarah.
\end{abstract}

Kata Kunci: Kerajaan Galuh, Kabupaten Galuh, Kadipaten Ciancang

\begin{abstract}
Galuh Regency historical development originated from the founding of the kingdom in Ciamis commonly referred to Galuh Kingdom or the Kingdom of Sunda Galuh. Galuh Kingdom is expressed in several historical sources, either through text or inscriptions. The manuscript mentioning Galuh Kingdom is classified into traditional historiography that contain elements of myths, fairy tales, legends, and the elements that are historical. Some texts that tell about the kingdom Galuh so many using traditional historiography, then a penulusuran scientifically Galuh history writing is needed for writing critically. This study uses historical research work is divided into four stages. First, the heuristics source collection phase. Second, critics are divided into external criticism and internal criticism, the third, namely the interpretation of the interpretation of the source, and the last is the historiography or the writing of history.
\end{abstract}

Keywords: Kingdom Galuh Galuh District, Duchy Ciancang

\section{PENDAHULUAN}

No document no history, itulah statement Leopold van Ranke seorang ilmuwan sejarah yang menjadikan sejarah satu kesatuan ilmu pengetahuan yang menggunakan perangkat metode sahih. Sejarah dalam karakteristiknya terbagi menjadi 3. Sejarah bersifat unik karena peristiwa, kedua, sejarah sebagai kisah, ketiga, sejarah sebagai ilmu. Sejarah yang menggunakan perangkat metodologisnya berupaya untuk mengenal dan menyelami kehidupan masa lampau dengan utuh. Maka dari itu sejarah disini sangat memerlukan disiplin ilmu-ilmu lain. Penggunaan ilmu bantu

\footnotetext{
* Penulis Koresponden

E-mail address: dewiratih@unigal.ac.id doi:
}

bergantung pada pokok bahasan periode sejarah yang tengah dipelajari, seperti Paleontologi, Paleoantropologi, Arkeologi, Paleografi, Epigrafi, Ikonografi, Numismatik, Ilmu Keramik, Genealogi, Filologi, Etnografi, Ilmuilmu sosial, Bahasa, Statistik, Komputer atau Internet (Sjamsuddin, 2007: 189-213).

Menganalisis awal mula lahir dan berkembangnya suatu peradaban tidak bisa kita lepaskan dari peran penting ilmu sejarah. Contoh peradaban yang lahir dan berkembang yang tercatat di dalam sejarah Indonesia lebih khususnya di daerah Ciamis. Penelitian mengenai sejarah Ciamis haruslah berdasarkan sumber sejarah yang memang menjelaskan

Copyright@2017 Jurnal Artefak e-ISSN: 2580-0027 
sejarah Ciamis. Sumber-sumber tersebut dapat bersumber dari naskah atau prasati.

\section{METODE PENELITIAN}

Metode dalam penelitian yang digunakan dalam penelitian jurnal ilmiah ini adalah metode sejarah (historis). Metode historis adalah sebuah upaya guna mempelajari juga mengenali faktafakta, lalu menyusun simpulan tentang kejadian pada masa lalu. Tujuannya adalah untuk membuat rekontruksi masa lampau secara sistematis dan objektif (Garraghan, 1957: 34). Tahapan penelitian dalam metode historis terbagi 4 tahapan kerja. Tahap pertama adalah heuristik atau pengumpulan sumber sejarah. Heuristik merupakan tahapan pertama yang harus dilaksanakan setelah penulis menentukan topik dan permasalahan penelitian. Heuristik sendiri adalah proses menemukan dan menghimpun sumber sejarah yang terkait dengan pokok pembahasan. Tahap pencarian sumber dilakukan terhadap sumber tertulis, sumber benda dan lisan. Sumber tertulis berupa arsip, sumber resmi tercetak, dokumen, buku dan lain-lain. Pencarian sumber primer yang sezaman berbentuk sumber resmi tercetak, naskah dan buku-buku sebagai acuan literatur dilakukan di beberapa perpustakaan, antara lain: Perpustakaan Nasional Republik Indonesia (PNRI) di Jalan Salemba Raya Nomor 28A, kemudian di BAPUSIPDA (Badan Perpustakaan dan Arsip Daerah Provinsi Jawa Barat) di Jl. Soekarno Hatta No. 629, Perpustakaan Fakultas Ilmu Pendidikan dan Ilmu Keguruan Universitas Galuh dan Perpustakaan Prodi Pend. Sejarah di Universitas Galuh Ciamis. Dilain pihak penelusuran sumber pun dilakukan dengan wawancara langsung kepada para keturunan yang ada dan masih mendiami lahan dan wilayah bekas salah satu Kadipaten, yang saat ini berada di Kabupaten Ciamis, dahulu bernama Kabupaten Galuh. Di perpustakaan Bapusipda, FKIP Universitas Galuh Ciamis dan Prodi Pendidikan Sejarah Universtias Galuh Ciamis dikhususkan kepada pencarian sumber sekunder (buku-buku) pendukung penelitian sumber sejarah lokal Kerajaan Galuh sampai Kabupaten.

Tahap selanjutnya adalah tahapan mengkritik sumber. Kritik sumber dalam metode historis terbagi menjadi dua. Diantaranya adalah kritik eksternal dan kritik internal. Kritik eksternal mempunyai tujuan menentukan otentisitas sumber dengan cara memberikan penilaian terhadap kondisi fisik sumber tersebut, seperti jenis kertas yang digunakan, tinta, tulisan, huruf, watermark, stempel dan sebagainya. Kritik intern dilakukan dengan melakukan penilaian terhadap kondisi fisik sumber tersebut. Terlebih sumber-sumber sezaman yang terlihat dari beberapa naskah yang ada dilihat dan dinilai isi dari naskah tersebut, meskipun kenyataannya sumber tersebut masih dalam bentuk sumber historiografi tradisional. Selain itu, akan dilakukan pula proses membandingkan data yang ada di dalam sumber tersebut dengan sumber lainnya.

Tahap selanjutnya adalah interpretasi. Interpretasi adalah proses menafsirkan berbagai fakta menjadi sebuah rangkaian yang logis. Pada tataran oprasionalnya interpretasi dilakukan secara analitis yakni mengurai fakta dan dilakukan secara sintesis yaitu menghimpun fakta. Pemahaman secara verbal tidak memadai untuk menginterpretasikan informasi yang ada di dalam sumber sejarah. Fakta yang diperoleh diinterpretasikan baik secara verbal, teknis, logis, faktual dan psikologis. Dengan demikian, hasil dari interpretasi dapat dipahami secara menyeluruh juga mendalam.

Tahapan terakhir dalam penulisan sejarah dengan menggunakan metode sejarah ialah Historiografi. Historiografi adalah tahapan penulisan sejarah. Fakta yang telah diinterpretasikan kemudian dituliskan dalam penulisan yang sistematis dan kronologis. Historiografi yang akan dihasilkan dibagi menjadi beberapa pembahasan, yang secara keseluruhan merupakan satu kesatuan yang utuh. Dengan menggunakan metode sejarah, penulis mendapat panduan bagaimana teknis penelitian jurnal ilmiah ini dapat dikerjakan secara efektif dan akurat. Efektif dalam pengertian tahap demi tahap dikerjakan dengan terperinci. Akurat dalam pengertian hanya sumber yang telah menjadi fakta sejarah yang bisa dijadikan bahan penulisan jurnal ilmiah ini. Selain itu, unsur diakronis yang menunjukan sejarah, sebagai ilmu tentang berfikir dalam waktu sangat diperhatikan.

\section{HASIL PENELITIAN DAN PEMBAHASAN}

Awal Kemunculan Kerajaan Galuh ditandai oleh sebuah prasasti, ditemukan di wilayah Jawa Barat menuliskan sejak berakhirnya Kerajaan Tarumanagara pada abad ke-7, berdiri pusat kekuasaan yang kemudian dikenal sebagai Kerajaan Sunda. Pusat kerajaan 
ini berpindah-pindah dimulai dari Galuh, kemudian ke salah satu tempat bernama Pakuan Pajajaran, Kawali dan terakhir kembali ke Pakuan Pajajaran (Bogor) (Herlina[b], 2013: 2039).

Dipercaya bahwa awal mula Kerajaan Galuh ada kaitannya dengan awal mula penciptaan manusia pertama yaitu Nabi Adam dan Siti Hawa ${ }^{1}$. Keturunan dari Nabi Adam ini memiliki 40 anak laki-laki juga 39 anak perempuan. Keturunan mereka salah satunya ialah Ratu Galuh (Prabu Adimulya atau Ratu Permana atau Permadikusumah). Pada awalnya Ratu Galuh mendirikan sebuah Negara di Lakbok dengan sebutan Medangkamulyan. Karena negara Medangkamulyan terkena bencana, Ratu Galuh bertapa untuk mencari wilayah Kerajaannya. Dalam pertapaan yang dilaksanakan oleh Ratu Galuh, sang Maha Kuasa memberikan petunjuk bahwa lokasi baru kerajaan terletak di daerah yang ada batu berwarna putih. Lokasi tersebut ternyata ada di pertemuan 2 aliran sungai yaitu Citanduy dan Cimuntur (Sekarang tempat itu dikenal Karangkamulyan di desa Cijeungjing Ciamis). Menurut tradisi yang hidup di masyarakat, Kerajaan Galuh ketika di Karangkamulyan diperintah oleh 13 orang Raja yaitu:

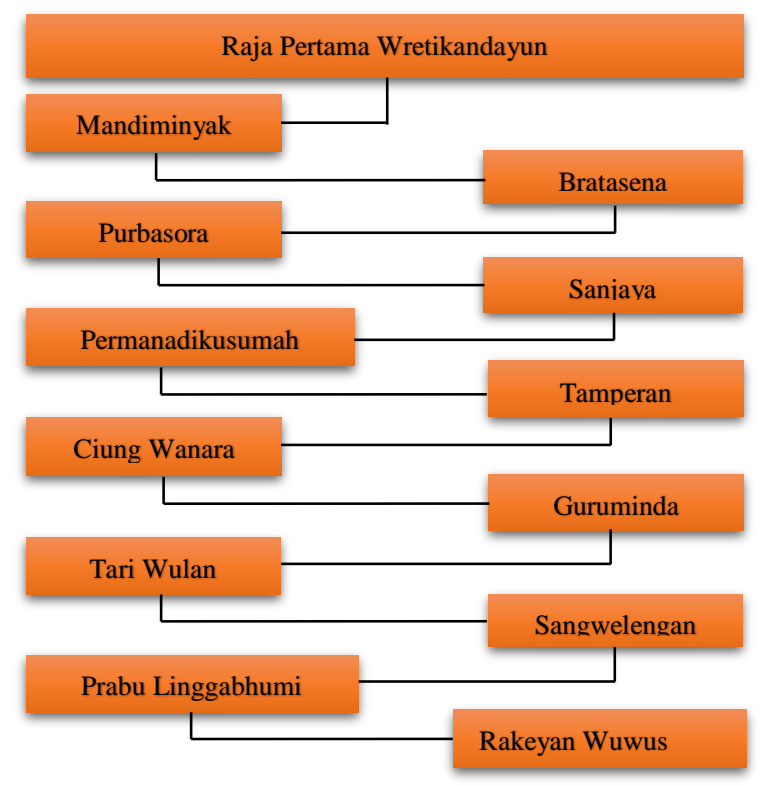

Sumber: Herlina [a], 2013: 39-47).

Periode Karangkamulyan dalam tradisi Kerajaan Sunda Galuh berakhir seiring dengan meninggalnya Rakeyan Wuwus. Berakhirnya periode Karangkamulyan bukan disebabkan karena serangan dari Kerajaan lain. Rakeyan Wuwus tidak memiliki anak sehingga tahta Kerajaan diserahkan kepada Dharmaraksa, suami adik perempuannya bertahta di Purasaba, pusat kekuasaan Kerajaan Sunda. Setelah menerima kuasa Kerajaan Galuh, Dharmaraksa memilih untuk tetap tinggal di Purasaba dan memasukan Kerajaan Galuh sebagai wilayah Kerajaan Sunda. Dengan demikian, pada masa Dharmaraksa ini, Kerajaan Sunda memiliki wilayah yang terbentang luas, mulai dari Nusa Apuy (Pulau Krakatau) hingga sekitar Kedu Jawa Tengah (Herlina[a], 2013: 44).

Beberapa abad kemudian, eksistensi Kerajaan Galuh kembali muncul dengan pusat Pemerintahannya di Kawali (di daerah Ciamis). Menurut tradisi lisan yang ada di Ciamis, penguasa pertama Kerajaan Galuh di Kawali adalah Umilestari atau Dewisantika putra Linggadewata. Umilestari menikah dengan Ajiguna Linggawisesa sehingga roda pemerintahan Kerajaan Galuh dijalankan oleh Linggawisesa bergelar Prabu Sang Linggawisesa. Setelah meninggal dunia, tahta Kerajaan diserahkan kepada Ragamulya Luhur Prabawa yang dikenal juga dengan sebutan Aki Kolot, masih dalam tradisi lisan di Ciamis, keadaan Kerajaan Galuh di Kawali tidak banyak dikisahkan pada masa Aki Kolot berkuasa. Kekuasaan kemudian berpindah ke tangan Prabu Maharaja Linggabuana, putra tertua Sang Aki Kolot. Prabu Linggabuana memiliki 3 orang putra yaitu, Dyah Pitaloka Citraresmi, Wastukencana, dan Ratna Parwati. Pada masa pemerintahan Linggabuana, terjadi peristiwa Bubat.

Peristiwa ini terjadi antara Kerajaan Galuh dengan Kerajaan Majapahit di Jawa Timur. Peristiwa Bubat atau Pasunda Bubat ini awalnya terjadi karena keinginan Raja Majapahit Hayam Wuruk yang ingin memperistri Dyah Pitaloka. Akan tetapi pernikahan itu gagal dilaksanakan karena sikap Patih Amangkubhumi Gajah Mada menginginkan Dyah Pitaloka menjadi upeti untuk Raja Hayam Wuruk. Keinginan tersebut sebagai upaya Gajah Mada untuk menjadikan Kerajaan Sunda sebagai wilayah kekuasaan Majapahit. Prabu Maharaja Linggabuana tentunya menolak keinginan Gajah Mada tersebut sehingga pertempuran Kerajaan Galuh dan Kerajaan Majapahit tidak terelakan di Pesanggrahan Bubat, dalam pertempuran itu,

\footnotetext{
${ }^{1}$ Berdasarkan naskah Wawacan Sajarah Galuh, diceritakan asal-usul Kerajaan Galuh yang berasal dari Nabi Adam dan istrinya Babu Hawa. Naskah tersebut adalah historiografi tradisional yang masih berbentuk mitos. Naskah tersebut ditulis pada 1886.
} 
Prabu Linggabuana juga Dyah Pitaloka gugur, tetapi Kerajaan Sunda tidak dapat dikuasai oleh Majapahit. Setelah Prabu Linggabuana meninggal dunia, kekuasaan atas Kerajaan Sunda Galuh diberikan kepada adiknya yang bernama, Bunisora. Ia merupakan Raja penyelang karena pewaris tahta Kerajaan, Niskala Wastukancana masih anak-anak. Setelah usia Niskala Wastukancana cukup, Bunisora menyerahkan tahta Kerajaan ke keponakannya. Setelah Niskala Wastukancana berkuasa di Kerajaan Sunda Galuh selama 104 tahun, kedudukannya sebagai Raja Sunda Galuh digantikan oleh putra keduanya Dewa Niskala, karena putra pertamanya Susuk Tunggal, menjadi Raja di Pakuan Pajajaran. Dewa Niskala kemudian menikah dengan putri Majapahit, terjadi ketegangan antara Susuk Tunggal di Pajajaran dengan Dewa Niskala. Ketegangan itu dapat diatasi setelah masing-masing menyerahkan kekuasaan Kerajaannya kepada pewarisnya. Dewa Niskala menyerahkan kuasa Kerajaan Sunda Galuh ke Jayadewata dan Susuk Tunggal menyerahkan tahta Kerajaan Sunda Pajajaran kepada menantunya Jayadewata. Dengan demikian Kerajaan Sunda Galuh dan Kerajaan Pakuan Pajajaran disatukan kembali oleh Jayadewata sehingga muncullah Kerajaan Sunda. Seiring dengan itu berakhirlah eksistensi Kerajaan Galuh di Kawali.

\section{Akhir Kerajaan Sunda}

Keruntuhan Kerajaan Sunda Pajajaran ditandai dengan kerajaan-kerajaan vassal bekas Kerajaan Sunda diakui ada di bawah Sumedanglarang oleh Geusan Ulun (15791601), kecuali Banten, Jayakarta, Galuh dan Chirebon (Herlina [a]. 2013:822). Banyak pendapat ketika runtuhnya Kerajaan Sunda Pajajaran, Kerajaan Galuh masih berdiri. Kerajaan Galuh waktu itu diperintah oleh Cipta Sanghiang putra Prabu Haur Kuning. Namun ketika Pakwan Pajajaran diislamkan oleh Banten, Kawali pun diislamkan oleh Cirebon. Pada awalnya Islam berkembang di Kerajaan Sunda oleh para pedagang muslim dari Malaka, tidak mau lagi singgah disana karena Malaka telah jatuh ke Portugis pada 1512. Pedagang muslim yang pindah dari Malaka menguasai pelabuhan-pelabuhan yang terdapat di sepanjang pantai utara Kerajaan Sunda.

Pelabuhan pantai utara Kerajaan Sunda menjadi ramai. Namun Raja Sunda (Sang Ratu Jayadewata) pada saat itu merasa khawatir akan pengaruh Islam yang semakin besar dan cepat berkembang. Raja Sunda yang masih memegang agama Hindu berusaha untuk mengantisipasi berkembangnya agama Islam dengan membatasi para pedagang muslim di pelabuhan milik Kerajaannya. Usaha untuk membatasi para pedagang muslim di pelabuhan Kerajaan Sunda sangat sulit dilaksanakan. Pedagang muslim tetap saja meramaikan pelabuhan Kerajaan Sunda. Kerajaan Sunda memilih untuk mengadakan koalisi dengan Portugis di Malaka (Herlina[a].2013:78).

Hubungan Kerajaan Sunda dan Portugis diawali pada 1512 ketika Ratu Jayadewata mengirimkan beberapa utusannya ke Malaka. Pada tahun 1513, Portugis melakukan ekspedisi untuk mencari informasi tentang peranan pelabuhan-pelabuhan di pesisir pantai utara Jawa. Diduga jalur yang menghubungkan ibukota Kerajaan Sunda dengan daerah kekuasannya adalah jalur menuju ke timur. Berawal dari Pakwan Pajajaran-CileungsiCibarusa-Desa Warungede-Tanjungpura (Karawang)-Cikao-Purwakarta-Karangsembung (tepian sungai Cimanuk), selanjutnya dari Karangsembung-Cirebon-Kuningan-Sindangkasih-Talaga berkahir di Kawali. Jalan ke arah bara bermula dari Pakwan Pajajaran - Jasinga Rangkas bitung - Serang - Banten.

Perjanjian politik yang dilaksanakan oleh Kerajaan Sunda bersama Portugis terrealisasikan ketika Henrique de Leme datang ke ibukota Kerajaan Sunda. Henrique diterima baik oleh Raja Sunda Ratu Samiam (setelah Sang Ratu Jayadewata). Kunjungan tersebut menghasilkan perjanjian politik Kerajaan Sunda bersama Portugis yang ditandatangi tanggal 21 Agustus 1522. Perjanjian tersebut ditandatangi Raja Sunda Ratu Samiam atau Prabu Surawisesa dan Henrique de Leme. Ratu Samiam didampingi tiga pembantu utama yaitu Mantri Dalam (Mandari Tadam), Tumenggung Sang Adipati (Tamugo Sanque de Pate), dan Syahbandar (Bengar Xanbandar). Henrique de Leme didampingi oleh Fernando de Almeida, Fransisco Anes, Manuel Mandes, Joao Coutinho, Gil Barboza, Tome Pinto, Sebastian de Rego, dan Fransisco Diaz. Perjanjian tersebut berisi kesepakatan sebagai berikut:

1) Portugis boleh membuat sebuah benteng disekitar Banten.

2) Raja Sunda memberikan lada berapapun yang dibutuhkan oleh Portugis, sebagai penukaran kebutuhan Kerajaan Sunda dibawa oleh Portugis. 
3) Portugis mau membantu Kerajaan Sunda jika diserang Kerajaan Demak atau kerajaan lainnya

4) Sebagai tanda hubungan politik antara Kerajaan Sunda bersama Portugis, Raja Sunda memberikan seribu karung lada $( \pm 350$ kuintal) setiap tahun kepada Portugis semenjak pembangunan benteng dimulai.

Portugis kemudian mendirikan loji di pelabuhan Kalapa dan mendirikan sebuah padrao sebelum meninggalkan Kerajaan Sunda (Herlina. 2013: 79-80). Keberangkatan Portugis dari Kalapa merupakan faktor terbaik dalam upaya Islam guna memperluas kekuasaannya di wilayah Jawa bagian barat. Carita Parahyangan menuliskan bahwa dalam upaya mempertahankan wilayah Kerajaan Sunda, Surawisesa berperang sendiri melawan pasukan muslim. Surawisesa berperang sebanyak lima belas kali dan tidak pernah kalah. Surawisesa berperang ke Kalapa, Tanjung, Ancol Kiji, Wahanten Girang, Simpang, Gunung Batu, Saung Agung, Rumbut, Gunung Banjar, Padang, Panggaokan, Muntur, Hanum, Pagerwesi dan Medangkahyangan. Sementara Surawisesa menginginkan bantuan Portugis, tidak kunjung datang, akhirnya Surawisesa harus meninggalkan ibukota Pakwan Pajajaran. Usaha keras Prabu Surawisesa akhirnya tak bisa membendung pengaruh Islam yang datang semakin besar. Banten dan Sunda Kalapa hingga dikuasai muslim (Gabungan pasukan Demak dan Cirebon) pada tahun 1526 - 1527.

Jatuhnya dua pelabuhan penting Banten dan Sunda Kalapa Kerajaan Sunda menjadi terisolir. Jalan dagang Kerajaan Sunda diblokir. Pasukan Portugis datang pada tahun 1527 ke Sunda Kalapa. Portugis harus berhadapan dengan pasukan Islam dipimpin Fatahillah. Portugis akhirnya dikalahkan dan pelabuhan Sunda Kalapa diganti menjadi "Jayakarta" yang berarti "kota kemenangan". Kerajaan Sunda yang terisolir dari dunia luar menjadi faktor eksternal dari keruntuhan Kerajaan Sunda. Pengganti Raja Sunda Prabu Surawisesa selanjutnya adalah Prabu Ratudewata (15351543).

Prabu Ratudewata pada dasarnya tidak menyukai dengan dunia politik dan perang. Prabu Ratudewata lebih memilih hidup sebagai
Pendeta untuk menghindar dari kekacauan di dalam negeri. Sementara serangan dari Banten terus-menerus terjadi, sehingga Raja Sunda terakhir beragama Hindu yaitu Nusiya Mulya (1567-1579) tidak dapat mempertahankan kerajaannya. Pasukan Islam tergabung (Demak, Cirebon dan Banten) berhasil memenangkan berbagai pertempuran dan wilayah Kerajaan Sunda seperti Rajagaluh, Kalapa, Pakwan, Galuh, Datar, Mandiri, Jawakalapa, Gegelang dan Salajo jatuh ketangan Banten. Kerajaan Sunda beragama Hindu berpusat di Pakwan Pajajaran benar-benar berakhir pada tahun 1579 M, karena serang dari Maulana Yusuf kesultanan Banten. Selanjutnya Pakwan Pajajaran diislamkan oleh Banten, sedangkan Galuh diislamkan oleh Cirebon.

\section{Galuh: Dari Kerajaan ke Kabupaten}

Masuknya Islam ke Kerajaan Galuh sekitar abad ke-16. Menurut cerita Kerajaan Galuh pada tahun $1580^{2}$ masih berdiri. Cerita tradisi menyebutkan masuknya Islam ke Kerajaan Galuh karena seorang tokoh yang bernama Apun diAnjung bernama Pangeran Mahadikusuma (Maharaja Kawali). Ia merupakan ulama yang mendapat kepercayaan dari Cirebon. Dikisahkan bahwa Prabu Cipta Sanghyang Raja Galuh mempunyai putra bernama Ujang Ngekel, jatuh cinta kepada Tanduran putri Raja Kawali Pangeran Mahadikusuma. Namun, Ujang Ngekel yang masih beragama Hindu, Pangeran Mahadikusuma memberitahukan hal tersebut kepada Sultan Cirebon. Ujang Ngekel kemudian dipersilahkan datang ke Cirebon dan ternyata Ujang Ngekel bersedia masuk agama Islam. Meskipun sudah beragama Islam, Ujang Ngekel oleh Kesultanan Cirebon diperbolehkan melakukan adat kebiasaan yang biasa dilakukan tradisi leluhur Galuh. Ujang Ngekel diberi gelar Prabu Galuh Cipta Permana ketika naik tahta dan berkedudukan di Gara Tengah.

Setelah Ujang Ngekel (Prabu Galuh Cipta Permana) meninggal, Wilayah Galuh dikuasai anaknya Sangian Dipati atau Adipati Panaekan. Tahun 1595 Galuh jatuh ketangan Mataram ${ }^{3}$. Beberapa sumber Belanda menuliskan batasbatas wilayah kekukasaan Galuh yang dikuasai Mataram diantaranya adalah: Sungai Citanduy

\footnotetext{
${ }^{2}$ Kerajaan Galuh kemungkinan masih berdiri ketika Kerajaan Sunda sudah runtuh pada tahun 1579 M. Hal ini ditandai dengan berkuasanya Raja di Galuh bernama Prabu Cipta Sanghyang di Galuh memerintah Kerajaan pada 1580 - 1595. Prabu Cipta Sanghyang merupakan keturunan dari Prabu Haur Kuning.

${ }^{3}$ Jatuhnya Kerajaan Galuh ke tangan Mataram masih berada dalam periode Pemerintahan Ujang Ngekel sekitar tahun 1595. Lihat Herlina, Nina et al (Sejarah Kabupaten Ciamis).
} 
(di sebelah timur), Sumedanglarang (di sebelah utara), Galunggung, Sukapura (disebelah barat) dan Sungai Cijulang (di sebelah selatan). Panembahan Senapati (penguasa Mataram) telah berhasil menancapkan pengaruh kekuasaan politiknya di wilayah Galuh. Meskipun secara intensif Mataram belum menguasai sepenuhnya. Panembahan Senapati masih mengakui kuasanya akan wilayah Galuh. Ia sebagai pemimpin Galuh memerintah tidak atas nama penguasa Mataram. Hal ini terlihat dengan masih dipakainya gelar Prabu Galuh Cipta Permana nama gelar Ujang Ngekel yang berkuasa di Galuh. Ketika Wilayah Galuh di kuasai Prabu Galuh Cipta Permana, pusat wilayah Galuh dipindahkan ke Gara Tengah (daerah sekitar Cineam, Kabupaten Tasikmalaya).

Penguasa Mataram setelah Panembahan Senapati adalah Sultan Agung. Suksesi kepemimpinan Sultan Agung di Mataram melantik Adipati Panaekan menjadi Wedana ${ }^{4}$ Mataram di Galuh. Sultan Agung memberi kekuasaan kepada Adipati Panaekan atas 960 cacah (rakyat) juga memerintah dibawah kuasa Mataram. Mataram kemudian merencanakan serangan kepada VOC di Batavia. Tahun 1628, wilayah vassal Mataram di Jawa Barat (Priangan) bersilang pendapat, Rangga Gempol I penguasa Sumedang, untuk menyerang VOC pertahanan diperkuat dahulu, namun Dipati Ukur, menghendaki serangan segera. Pertentangan pendapat terjadi pula di wilayah Galuh. Adipati Panaekan dengan adik iparnya Adipati Kertabumi, yang menjadi Bupati di Bojonglopang, anak dari Prabu Dimuntur dan keturunan Geusan Ulun dari Sumedang. Dalam perselisihan ini Adipati Panaekan terbunuh pada tahun 1625, ia kemudian digantikan oleh putranya yang bernama Adipati Imbanagara (Herlina[b].2013:27).

Sultan Agung kemudian menyerang Batavia, tahun 1628-1629. Adipati Imbanagara memberikan bantuan pasukan di bawah Bagus Sutapura. Penyerangan Sultan Agung ke Batavia mengalami kegagalan, diantaranya adalah Dipati Ukur sebagai komandan pasukan Mataram melaksanakan pemberontakan kepada Hegemoni Mataram dan bertujuan membebaskan wilayah Mataram. Konon, orang yang berhasil menangkap Dipati Ukur ialah Bagus Sutapura pemimpin pasukan Galuh. Atas jasanya itu Bagus Sutapura oleh Mataram dijadikan Bupati di Kawasen. Setelah tahun 1676 wilayah Kabupaten Kawasen dimasukan kedalam wilayah Kabupaten Imbanagara.

Dipati Imbanagara kemudian dituduh bersekongkol bersama Dipati Ukur untuk melawan sistem kekuasaan Mataram di Jawa bagian Barat. Pada tahun 1636 Sultan Agung kemudian menghukum mati Adipati Imbanagara. Putra Dipati Imbanagara Mas Bongsar yang berusia 13 tahun untuk sementara dijadikan Bupati Galuh. Di bawah perwalian Patih Wiranangga meminta piagem pengangkatan keponakannya sebagai Bupati Galuh, akan tetapi Patih Wiranangga mengubah isi piagem tersebut. Ditulislah nama Patih Wiranangga yang dijadikan Bupati Galuh di Gara Tengah. Perilaku curang Patih Wiranangga ini diketahui oleh Ki Pawindan pengikut setia Mas Bongsar. Ki Pawindan menemukan piagem asli pengangkatan Mas Bongsar menjadi Bupati Galuh di (kolong) rumahnya di Padaherang. Mas Bongsar diangkat menjadi Bupati Galuh tanggal 5 Rabiul Awal Tahun Je (6 Agustus 1636) dan dianugerahi gelar Raden Panji Aria Jayanegara. Sultan Agung memberi saran kepada Mas Bongsar agar menamai kabupaten yang dipimpinnya menggunakan nama ayahnya yaitu Imbaganara. Tahun 1636 Gara Tengah diganti namanya menjadi Imbanagara, disamping Bojonglopang (Kertabumi) dan Kawasen.

Sultan Agung melakukan reorganisasi wilayah Barat pada tahun 1641. Wilayah Priangan dipecah menjadi empat Kabupaten, yaitu Sumedang larang, Bandung, Parakan muncang dan Sukapura. Galuh kemudian dipecah menjadi 5 Kabupaten yaitu, Imbanagara, Bojonglopang, Ciancang (Utama), Kawasen (Banjarsari) dan Banyumas. Reorganisasi wilayah Mataram di bagian barat dilanjutkan oleh penerus Penguasa Mataram sesudah Sultan Agung yaitu Amangkurat I. Tahun 1645 Amangkurat I membagi wilayah bagian barat menjadi dua belas Kabupaten diantaranya adalah Sumedang, Bandung, Parakanmuncang, Sukapura, Karawang, Imbanagara, Kawasen, Wirabaya (Galuh/Bojonglopang), Sekace, Banyumas, Ayah dan Banjar. Bagi R.P.A Jayanegara (Mas Bongsar) wilayah Gara Tengah yang diberinama Imbanagara merupakan daerah yang memberikan kenangan buruk. Ditempat ini kakek dan ayah dari R.P.A Jayanegara terbunuh

\footnotetext{
${ }^{4}$ Wedana = Bupati. Pengangkatan Adipati Panaekan sebagai wedana merupakan hal yang pertama kali dilakukan oleh Sultan Agung di wilayah Jawa bagian Barat sehingga Adipati Panaekan dikatakan sebagai “De oudste der wedana's in der Wester Ommelanden (van Mataram).
} 
menjadi korban pertentangan politik diantara penguasa Galuh.

R.P.A Jayanegara akhirnya memindahkan kekuasaan dari Gara Tengah ke daerah Calingcing, kemudian dipindahkan ke Bendanegara (Panyingkiran) dan terakhir ke Barunay. Daerah Barunay jika dilihat pada saat ini berada diantara Cikoneng-Kota Ciamis sekarang. Kedudukan Barunay kemudian berubah nama kembali menjadi Imbanagara, sebagai ibukota Kabupaten Imbanagara berlangsung sampai tahun 1815 . Kabupaten lain seperti Kertabumi, Utama, Kawasen, Panjalu dihilangkan sehingga wilayah Kabupaten Imbanagara mempunyai daerah yang cukup luas. Wilayahnya terbentang dari Cijolang sampai pantai selatan, juga dari Citanduy timur hingga perbatasan Sukapura. Beberapa wilayah yang berada di sebelah timur Citanduy seperti Dayeuh Luhur, Nusa Kambangan, Cilacap, dan Banyumas merupakan wilayah perwalian Kabupaten Imbanagara.

Peta: Topografi Kabupaten Galuh dalam wilayah Kersidenan Cirebon pada Pertengahan Abad XIX

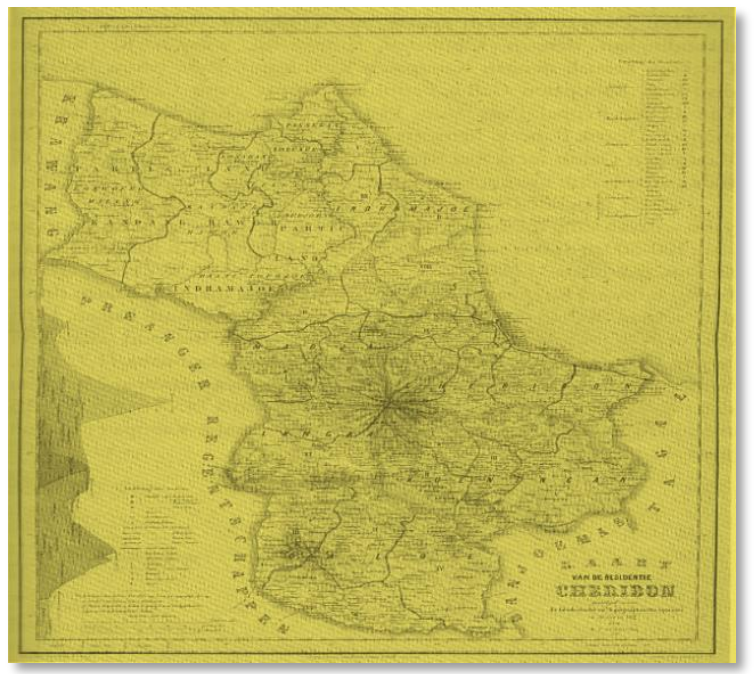

(Sumber: P. Baron Melvill van Carbee en W.F Versteeg. 1853-1862. Algemeene Atlas van Nederlandsch Indie. Batavia: van Haren Noman \& Kolff).

\section{Keberadaan Kadipaten Ciancang}

Kerajaan kecil atau biasa disebut dengan sistem Kadipaten di Ciancang pada dasarnya merupakan vassal Kerajaan Galuh. Perkembangan selanjutnya Ciancang mempunyai kedudukan yang sama dengan Kabupaten lain di Priangan. Ciancang (Kabupaten Utama) ikut ada di bawah kekuasan Mataram pada Sultan Agung memerintah di Galuh dan Sumedanglarang. Ciancang yang berawal dari wilayah Galuh Kertabumi dibentuk oleh Raja Galuh Maharaja Sanghiyang Cipta dan berkedudukan di Galuh Salawe Cimaragas. Ciancang berawal dari putri Raja Galuh bernama Tanduran Ageung yang menikahi Rangga Permana putra dari Prabu Gesan Ulun, Sumedang Larang ${ }^{5}$. Setelah menikah ia diberi hadiah wilayah Muntur, tepian sungai Cimuntur. Kemudian berdirilah wilayah Galuh Kertabumi.

Galuh Kertabumi berpindah-pindah ibukota. Diawali di wilayah Pataroman, Banjar tahun 1608-1618 oleh Dalem Wiraperbangsa atau Adipati Singaperbangsa I, lalu pindah lagi ke Liunggunung pada tahun 1630-1641 $\mathrm{M}^{6}$ oleh Adipati Singaperbangsa II. Pusat pemerintahannya kemudian berpindah ke Bojonglopang oleh Singaperbangsa III atau Dalem Pagergunung pada tahun 1641-1654 M. Pusat pemerintah Kertabumi akhirnya berpindah ke Kadipaten Ciancang tahun $1655 \mathrm{M}$ oleh Adipati Panatuyuda I atau Wiraperbangsa/Singaperbangsa IV. Keturunan Adipati Kertabumi oleh Mataram dituliskan dalam sebuah surat. Isi dari surat tersebut adalah sebagai berikut :

"Mangka emut kana piagem Kanjeng ka Ki Rangga Gede ti Sumedang, anu dititipkeun ka si Astrawadana. Anu matak manehna mawa piagem, lantaran manehna (Astrawadana) ngemban tugas ngareksa tanah kagungan Ratu "Nagara Agung.

Eta kaprabon beulah kulon diwatesan $k u$ Cipamingkis jeung beulah wetanna $k u$ Cimalaya. Saterusna Astrawadana kudu nungguan lumbung pare, anu eusina aya lima tangkes tilu belas jait. Eta pare engkena kudu diangkut ku Singaperbangsa, saupama parentahna geus katarima. Eta

\footnotetext{
${ }^{5}$ Keterangan lain menyebutkan bahwa Tanduran adalah putri Maharaja Kawali Pangeran Mahadikusuma bukan Putri dari Raja Galuh. Tanduran sang Putri Maharaja Kawali ini pun sudah memeluk agama Islam. Dituliskan bahwa yang masih beragama Hindu dan keturunan dari Kerajaan Galuh adalah Ujang Ngekel. Melihat permasalahan seperti itu Pangeran Mahadikusuma melaporkan kepada Sultan Cirebon. Ujang Ngekel Raja Galuh yang beragama Hindu akhirnya memeluk agama Islam.

${ }^{6}$ Keterkaitan Adipati Singaperbangsa I dan Ki Warasaba dalam pemerintahan di Ciancang atas dasar kepentingan Mataram yang masih menguasai daerah Sunda (Galuh dan Sumedanglarang). Setelah peristiwa perlawanan Dipati Ukur di Tatar Ukur Sultan Agung dari Mataram mengangkat Adipati Singaperbangsa I dan Ki Warasaba dari Banyumas sebagai Wedana untuk mengamankan kepentingan Mataram disebelah barat (sekitar daerah Karawang).
} 
surat parentah tea baris disanggakeun $\mathrm{ku}$ Ki Yudabangsa jeung Ki Wangsataruna, anu ayeuna aya di satengahing jalan mawa jalma reana dua rebu.

Eta jalma anu dua rebu tea baris dicangking $k u$ Singaperbangsa jeung $K i$ Wirasaba sacara wadana. Duanana geus diangkat $k u$ Ratu. Upama surat angkatanana geus beunang, maranehna kedah diperenahkeun di Waringin Pitu jeung Tanjungpura. Tugasna ngajaga nagara Agung ti beulah kulon bisi aya musuh.

Ieu piagem ditulisna poe Rebo tanggal sapuluh Mulud tahun Alif. Anu nulisna Anggaprana”.

Perhitungan Brandes, penanggalan yang tercantum di dalam piagem ini bertepatan tahun 1633. Adipati Singaperbangsa II yang ketika itu sedang menjadi wedana di Karawang, memberikan kekuasaan Ciancang kepada anaknya Candramerta. Perpindahan pusat Kerajaan Kertabumi dari Pataruman ke Liunggunung hingga ke Ciancang dikarenakan masukan dari keluarga yang ingin mendekati leluhur yaitu Prabu Dimuntur. Prabu Dimuntur (Pangeran Rangga Permana) ini adalah pendiri Wilayah Galuh Kertabumi. Prabu Dimuntur diceritakan melalui tradisi lisan ialah putra dari Geusan Ulun (Sumedang Larang).

Menurut keterangan, wilayah Ciancang pernah diserang oleh penjarah yang disebut dengan Pasukan Wetan. Penyerangan tersebut dilakukan sebanyak tiga kali. Pada saat itu penjahat dari Banyumas sekitar 2.000 orang datang dan menyerang wilayah Ciancang, akibatnya banjir darah terjadi peristiwa tersebut kemudian dikenal dengan Bedah Ciancang. tempat kejadian tersebut, di duga berada di dusun Cibeureum desa Utama (Ciancang) Kecamatan Cijeungjing Kabupaten Ciamis. Penyerangan dilakukan tiga kali:
1. Pemerintahan Ny. Rd. Ayu Rajakusumanagara/Dalem Isrtri (1718-1736 M)

2. Pemerinatahan Dalem Adipati Jayakusu Manggala/R.d. Tum. Wiramnatri II (1736$1762 \mathrm{M})$

3. Pemerintahan Dalem Adipati Surianagara/R.d Tumenggung Wiramantri IV (1787-1789 M)

Pada saat penyerangan Ny. Rd. Tejakusuma diduga lari karena menghindari serangan yang dilakukan oleh para penjarah dari Banyumas. Rd Tejakusuma selamat hingga akhirnya mempunyai keturunan. Atas dasar penyerangan itu pada masa Kyai Mas Jalipan/Panembahan Warganala IV, nama Ciancang di hapuskan dan diganti menjadi Utama dengan perhitungan mundur dari bilangan Nista (tiga), Maja (dua) dan Utama (satu).

Ciancang didirikan pada tahun 1655 oleh Dalem Wirasuta atau Singaperbangsa VI yang bergelar Adipati Panatayuda I perpindahan dari Kertabumi. Beliau menjadi bupati Ciancang selama tiga tahun karena mendapat tugas menjadi bupati Karawang dan membasmi para penjahat yang sering mengganggu ketertiban wilayah Mataram sebelah barat. Ketika beliau menjadi bupati Karawang kekuasaan Ciancang di pegang oleh anaknya yaitu Candramerta. Wirasuta adalah putra dari Apun Pagergunung (bupati Kertabumi IV) beristeri Nyai Ajeng Asrinagara, puteri Dalem Jangpati Jangbaya. Apun Pagergunung (bupati Kertabumi IV) ayahnya adalah Apun Tambakbaya (Bupati Kertabumi V). Sang Raja Cita (Adipati Kertabumi I) adalah ayah dari Apun Tambakbaya. Silsilah ini sampai pada Prabu Dimuntur pendiri Kerajaan Galuh Kertabumi. Bila ditelusuri lebih jauh Ciancang adalah tetesan dari darah Prabu Dimuntur atau Pangeran Rangga Permana.

\section{Silsilah Kerajaan Ciancang}

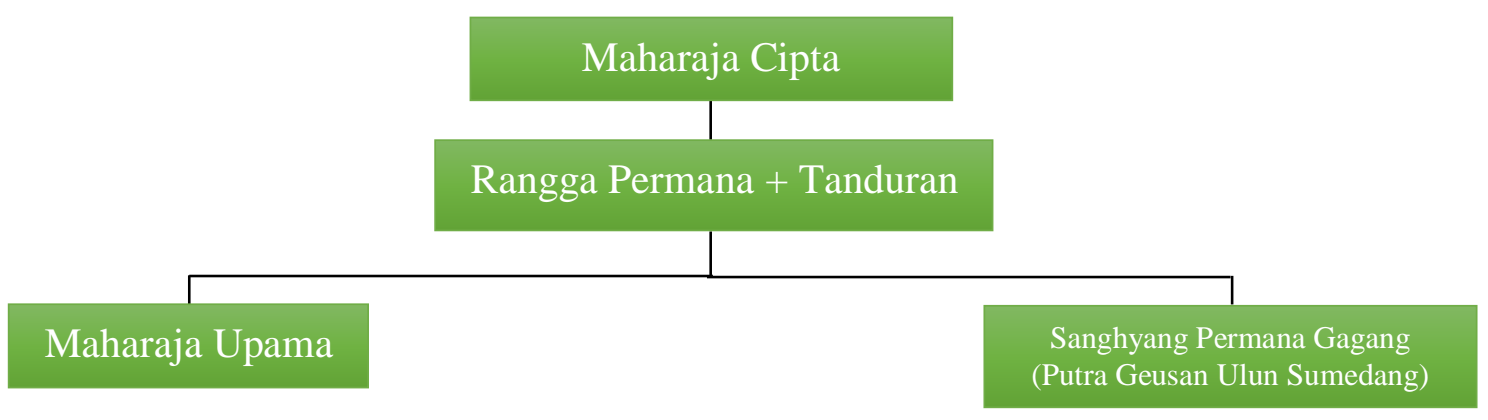


Bupati Kertabumi :

1) Sang Raja Cita (1602-1608) Bupati Kertabumi II

2) Singa Perbangsa I (1608-1618) Bupati Kertabumi III

3) Singa Perbangsa II (1630-1641) Bupati Kertabumi IV

4) Singa Perbangsa III (1641-1654) Bupati Kertabumi V

5) Singa Perbangsa IV (1654-1656) Bupati Kertabumi VI (Memindahkan pusat kekuasaan dari Bojonglopang ke Ciancang)

\section{Bupati Ciancang}

1) Dalem Apun Candramerta/Rd. Tumenggung Candramerta (1656-1658)

2) Dalem Demang Sutabaya/Rd. Adipati Singanagara (1658-1675)

3) Dalem Wiranegara/Rd. Tumenggung Warganata (1675-1683)

4) Dalem Apun Puspanagara/Rd. Tumenggung Jiranagara (1683-1685)

5) Pangeran Warganagala I (1685-1700)

6) Dalem Apun Candramerta (1700-1714)

7) Ny. Rd. Ayu Rajakusumanagara/Dalem Istri (1718-1736)

8) Dalem Wertanaya/Rd. Tumenggung Wiramnatri (1718-1736)

9) Dalem Adipati Jaya Manggala/Rd. Tumenggung Wiramnatri II (1736-1762)

10) Dalem Adipati Suriakusuma/Rd. Tumenggung Wiramnatri III (1762-1787)

11) Dalem Adipati Surianagara/Rd. Tumenggung Wiramnatri IV (1787-1789) dan (1789-1803)

12) Panembahan Warganala IV/Kyai Jalipan (1789-1791).

\section{PENUTUP}

\section{Simpulan}

Tahun sebelum 1915, wilayah Kabupaten Ciamis dikenal dengan nama lain yaitu, Kabupaten Galuh. Sebelum menjadi sebuah Kabupaten, nama Galuh sendiri adalah nama dari sebuah Kerajaan besar yang berada di Tatar Sunda sebelah selatan. Naskah Carita Parahyangan sendiri menuliskan bahwa di Tatar Sunda pernah berdiri dua buah Kerajaan yang selalu bersaing satu sama lain, Kerajaan itu adalah Kerajaan Sunda dan Kerajaan Galuh. Kedua Kerajaan itu dikenal pula dengan nama ibukota Kerajaannya masing-masing, yaitu Galuh Pakwan dan Pakwan Pajajaran. Pada sejarah panjang perjalanan eksistensi dua Kerajaan ini kerap berseteru juga kadang bersatu dibawah satu kekuasaan yaitu Raja Sunda. Setelah kekuasaan Islam dan pemerintah kolonial berkuasa di wilayah ini, sistem Kerajaan kemudian diubah menjadi sebuah wilayah bernama Kabupaten.

Berdirinya Kabupaten Galuh menarik perhatian tersendiri ketika kita akan menjelaskan wilayah-wilayah bekas Kerajaan vassal Kerajaan Galuh yang luas. Eksistensi bekas wilayah kerajaan Galuh kemudian berangsurangsur ikut berubah menjadi Kadipaten. Galuh kemudian biasa dikenal dengan sebutan "Tatar" atau hamparan Kadipaten bekas wilayah Kerajaan Galuh. Kadipaten yang tertulis dan menarik untuk dikaji adalah Kadipaten Ciancang yang dikemudian hari berubah menjadi Desa Utama (diambil dari bekas peristiwa "bedah Ciancang") "Nista", "Maja", "Utama". Kadipaten Ciancang yang didirikan pada awal abad ke-17 mengalami banyak pertempuran dan penyerang dari wilayah timur atau biasa disebut dengan "pasukan wetan". Pertempuran Ciancang ini kemungkinan besar awal dari perubahan nama Kabupaten Galuh yang berubah menjadi Kabupaten Ciamis saat ini.

\section{DAFTAR PUSTAKA}

Herlina, Nina[a] (et al). (2013). Sejarah Kabupaten Ciamis. Dinas Pariwisata dan Kebudayaan Provinsi Jawa Barat: Bandung.

. [b] (et al). (2013). Sejarah Kota-kota lama di Jawa Barat. Dinas Pariwisata dan Kebudayaan Provinsi Jawa Barat: Bandung.

------. (2009). Historiografi Indonesia dan Permasalahannya. Satya Historika: Bandung.

P. Baron Melvill van Carbee en W.F Versteeg. (1853-1862). Algemeene Atlas van Nederlandsch Indie. Batavia: van Haren Noman \& Kolff

Sjamsuddin, Helius. (2007). Metodologi Sejarah. Penerbit Ombak: Yogyakarta. 
Jurnal Artefak: History and Education, Vol.4 No.1 April 2017 